\title{
Taxpayers in business
}

'Whether the Post retains editorial independence remains to be seen. The Post's past editorial policy has supported media independence. Perhaps the first ominous sign is the Post's lack of editorial comment on the deal.'

\section{By RICHARD NAIDU}

"GOVERNMENT", Fiji's Finance Minister Jim Ah Koy is fond of saying, "is not in the business of business." In pursuit of that dictum, Government has in the last few years sold or prepared for sale its shipyard, its airline, the telephone system, the national bank and the hardwood forests, to name a few.

In business, argues the Government, it is no longer true that "Government knows best", PRIVATISATION is the buzz word and "leave it to the private sector" is the catch phrase.

There are exceptions to every rule and the Government exceptions are perverse. A few years ago, it decided to buy Lyle Cupit's Navua farm. "Youth training" was suddenly a business for which Government needed to be in business. Viti Corp was born.

Many moons and seven million dollars later, the grateful taxpayers have added a few tonnes of taro to the national wealth, but the hordes of youth trained in fish farming and cattle rearing have not materialised.

And then, on about 24 hours' notice, we, the people, learn that we will become owners of 44 per cent of our second daily newspaper, the Daily Post. As I understand it (and the available information is not much to go on), the Fiji Development Bank was a reluctant shareholder in the Post, having converted its past years' loans to the Post into shares, which at least avoided the difficult question of why the loan wasn't being repaid.

Then (the story goes) along came a syndicate led by C J Patel, a distributor 16 PACIFIC JOURNALISM REVIEW 5:1 1999 
of a variety of consumer goods with an advertising budget - and appetite - to match. The private sector was on the march. Market forces moved and a deal was done, or virtually done, with the development bank. Enter the Minister of Finance. FDB walks away from the C J syndicate and the Minister steps up with his cheque.

The only publicly stated reason I can recall for the minister's action was that the FDB was not managing this investment well enough. Government, it seems, knows best.

If my information is correct, the difference between the $\mathrm{C} \mathrm{J}$ syndicate offer and the Government's was negligible. Why, then, did Government spend $\$ 506,000$ of unbudgeted funds to buy shares which, according to at least one source, are backed by assets worth less than half that amount?

And if Government has decided it will micro-manage all of FDB's underperforming investments, how long will it be before we, the people, own a heap of bus companies and fishing boats ?

And what has the Fiji Development Bank, created by an Act of Parliament to act independently of Government, got to say about this? Do we assume it is meekly accepting Ah Koy's views of its performance?

Now, what about the rather odd coincidence that the Government acquisition of 44 per cent of a daily newspaper takes place three months out from a general election?

Aw, shucks, says the Prime Minister. Government's bank owned it anyway, what's the big deal? Government points out that it owns Radio Fiji. That is a rather unfortunate example if you listen to the Radio Fiji news. When was the last time Radio Fiji veered controversially from its staple diet of Government press releases and the otherwise blindingly obvious?

Whether the Post retains its editorial independence remains to be seen. The Post's past editorial policy has supported media independence. Perhaps the first ominous sign is the Post's lack of editorial comment on the deal that changed its ownership.

Newspapers are critical players in election campaigns. Hypersensitive politicians alternatively sidle up to them in the friendliest way and blast them for giving too many column centimetres to their opponents. This is a government primed with the belief in the rightness of its cause. It believes that "balance" in the media means half the stories about government should be good ones. It unblushingly uses public funds to attack its political opponents in newspaper advertisements apparently aimed at "clarifying misinformation". 


\section{RICHARD NAIDU}

So substantial ownership of a daily newspaper offers many tempting advantages. Editors and reporters can be pressured. Promotions and inducements can be withheld from reporters.

But heavy-handedness of this kind is not really necessary.

"All we ask," Ah Koy is reported by the Post as saying (on page 1, of course), "is be fair and accurate." Of course, Ah Koy's editorial standards in this respect may not be quite the same as someone else's.

Journalists are human beings and biting the hand that feeds them is never done lightly. So whether or not the Government intended it, the fact of its shareholding will be to render the Post tainted, politicised, and suffering from suspicion about its editorial policy.

As usual, the Parliamentary Opposition tried to make an issue of the deal and the Government, as governments do all over the world, rode out the attack, confining it to a "24-hour wonder". But the Government must tell us why its money was spent in this way.

Was there another private sector deal available to the Fiji Development Bank? And if so, why did it need to be put aside? How did the Government decide that $\$ 500,000$ was a good price to pay for this investment?

Where will the Government get its funds from? Ah Koy's own rule is no supplementary expenditure after the Budget. What was so special about the Post that it needed to be "invested" in?

People die in our hospitals because there are insufficient funds to equip them. Young Fiji citizens lose opportunities to enhance their education for lack of scholarship money. If the Minister of Finance wants to flex his entrepreneurial muscles with the Government's money, taxpayers deserve to know why.

$\square$ Richard Naidu is a lawyer and former journalist. He acts for the rival daily newspaper company, Fiji Times Ltd, and declares his interest. This article was published originally under the title "Taxpayers are back in business" in the Fiji Times, 28 February 1999. 